\title{
COMPARISON OF E-LEARNING AND Classroom Training FOR BACHELOR STUDENTS OF TRADITIONAL MEDICINE
}

\author{
Bazarragchaa Sodnom ${ }^{1}$, Uranchimeg Tudevdagva ${ }^{2,3}$, \\ Tserendulam Luvsandorj ${ }^{1 *}$, Selenge Erdenechimeg ${ }^{1 *}$ \\ ${ }^{1}$ Mongolian University of Pharmaceutical Sciences, Mongolia \\ ${ }^{2}$ Faculty of Computer Science, Technical University of Chemnitz, Germany \\ ${ }^{3}$ Power Engineering School, Mongolian University \\ of Science and Technology, Mongolia
}

\begin{abstract}
This paper describes a test and case study of self-evaluation of online courses during the pandemic time. Due to the Covid-19, the whole world needs to sit on lockdown in different periods. Many things need to be done in all kinds of business including education sector of countries. To sustain the education development, teaching methods had to switch from traditional face-to-face teaching to online courses. The government made decisions quickly, and educational institutions had no time to prepare the materials for online education. All classes of the Mongolian University of Pharmaceutical Sciences switched to online lessons. Challenges were raised before professors and tutors during online teaching. Our university did not have a specific learning management system for online education and e-learning. Therefore, professors used different platforms for their online instructions, such as Zoom and Google meet.
\end{abstract}

Moreover, different social networking platforms played an active role in communication between students and professors. The situation is challenging for professors and students. To measure the quality of online courses and figure out the positive and weak points of online teaching, we need to evaluate e-learning.

\section{KEYWORDS}

E-learning, classroom training, evaluation, traditional medicine, Mongolian university of pharmaceutical sciences.

\section{INTRODUCTION}

The Mongolian University of Pharmaceutical Sciences, the leading private university in pharmacy was founded in 2000 and it offers courses in Pharmacy, Traditional Medicine, Pharmaceutical Engineering and Technology, and Nursing. The Drug Research Institute and the GMP-Pharmaceutical Industry are the main components of the Mongolian University of Pharmaceutical Sciences (MUPS), and it has the great advantage of training to conduct a combination of Training-Research-Industry.

Pharmacists have a huge responsibility to human health and can work in many fields, including research, manufacturing, drug marketing, foreign relations, pharmacist, and clinical pharmacist. As of 2018, there were 2,169 pharmacists who work for drug-stores, hospitals, pharmaceutical industry throughout Mongolia, of which 395 new graduates, $31.6 \%$ or 125, were graduates of the MUPS [1]. 
International Journal on Integrating Technology in Education (IJITE) Vol.10, No.2, June 2021

Due to the global pandemic, it was moved on public alert in Mongolia by Resolution No. 62 of February 12, 2020, and Resolution No. 178 of November 11, 2020 of the Government of Mongolia, and classroom learning at Universities and Colleges were temporarily closed and continue to move to a form of online learning [2]. E-learning has expanded since last year in all kind of education.

As of April 15, 2021, the total number of confirmed cases of Covid-19 pandemic in Mongolia has reached 18,565, and it has spread rapidly in Mongolia and around the world, killing many people and causing irreparable damage and social and economic hardship in many countries.

Starting from the second semester of 2019-2020, the MUPS moved from classroom learning to online learning. As well as the first semester of 2019-2020, a total of 3001 video lessons, 489 enclosed files, and 41056 online test databases were created and 18,534 hours of electronic lectures, seminars and workshops were organized under basis of the cloud program [2]. From here, a total of 36 subjects of 93 credit hours, including general academic, professional foundation, and specialization, are taught online to first to fifth year students in pharmacy. As of the first quarter of 2020, a total of 1277 students are studying at the MUPS, of which 1062 are studying in the Pharmacy Department. Our study involved 552 students, including 52 male and 500 female students.

The MUPS is a branch of a large group of companies in Mongolia and provides internships in pharmaceutical companies, pharmaceutical research institutes, drug suppliers, and pharmacies, and conducts training that combines theoretical knowledge and practical skills. Due to the Covid19 epidemic, internships in these areas have been limited, nevertheless we aim to demonstrate the practical application of all science subjects online. Therefore, we conducted a comparative study of classroom and online lessons to determine what to look for in online lessons in the future.

-The "Vision-2050" long-term development policy of Mongolia, the medium-term development plan of the education sector of Mongolia 2021-2030, and the Government action plan set the goal of "creating equal opportunities for everyone to receive quality education and strengthening the system of equal inclusion" [3]. In the future, it is necessary to reform the legal environment of the education sector in order to live and work in the age of digital technology, and to develop a humane and ethical citizen with active social participation and continuous development potential. In order to implement these policy objectives, there is an urgent need to reform the legal environment in the education sector.

A draft law on education has been drafted and a nationwide online voting and discussion has been organized since November 5 this year. The project was accessed by more than 59,000 citizens, teachers, staff, parents and students, and 24,381 comments were received. Of the more than three million people in our country, one million are students and two million are their parents, families and future employers. Therefore, there are almost no citizens and families who are not involved in the activities of the education sector and do not receive their services.

The draft law includes many new regulations. Priorities include reforming the purpose and content of education, respecting and protecting the rights of students, ensuring their learning environment, strengthening the reputation of teachers, establishing working conditions, and ensuring social security. It also seeks to change the classification and type of educational institutions, to adhere to the principle of merit in appointing education officials, to ensure the right of students with disabilities to education in order to make education accessible and equal as well as to provide equal opportunities to obtain educational services regardless of where children with disabilities live. 
International Journal on Integrating Technology in Education (IJITE) Vol.10, No.2, June 2021

In addition, for the first time, the draft law regulates global development trends, the electric transition in education, online-learning, distance learning, and open educational resources to provide citizens with equal and accessible access to education. This is the first time that electric learning, technology and content have been legalized.

Mongolia needs to have a well-structured, integrated research university that combines teaching and research in present and future, when the world needs to improve its competitiveness, efficiency, and rapid development of communication and information technology. Consequently we need to compete as a world-class university.

In one day, 45,000 urban and rural children were connected to the online learning for high school students. In this way, online learning and online communication are being rapidly introduced to the education sector. Therefore, the new law provides for the organization of trainings and activities in kindergartens and secondary schools in addition to classroom training in the form of distance, electronic and mixed forms; the law provides for the publication of general education textbooks in both print and electronic formats.

Accordingly, the teacher must have the knowledge and ability to organize non-classroom, mixed forms of training; to support the continuous development of the teaching profession at the national level by organizing trainings on teaching methods and professional skills development in a centralized, regional, distance and electronic form. In addition, communication, information technology infrastructure, software and hardware for distance and electronic education are the responsibility of the relevant departments [4]

It has been a long time since the introduction of online learning management system in the Mongolian education system. A common challenge for today's educational institutions is to manage online learning activities, disseminate training content, monitor student learning, motivate teachers and students in the learning process, and required the development of a learning environment to improve indicators, methodologies, and models for evaluating learning activities.

Although there are many examples and experiences of universities in developed countries using electronic learning systems, and it's clear that the most important thing is to adapt these systems to the characteristics of the country's education system and to develop a new system that suits the country's education system and reflects the needs of educational institutions [5].

Due to the outbreak of Covid-19, a new corona virus pandemic, classroom learning was banned from the spring semester of the 2019-2020 academic years. The introduction of fully online learning was a major challenge for the entire community, as many teachers who were not systematically trained in online learning techniques conducted the full course online for the first time throughout the semester.

Each teacher went online and faced various problems, but each of them was able to solve the problem on their own and continue the training. However, in this article, we have selected our own assessment for a bachelor's degree in Pharmacy in order to evaluate our learning process, draw conclusions, and clarify our focus on future electric learning.

\section{Evaluation OF E-LeARNing}

Evaluation of e-learning is one of main points of discussion for researchers. Many researchers and educators developed different methods for evaluation of e-learning. A successful e-learning can run as result of collaboration where many different groups are working together: Professors, 
Technical people, Administration, Tutors, Students and others. Therefore evaluation of e-learning can be done in different complexity and level. As defined Christopher Pappas, evaluation of elearning was done before, during and end of e-learning. These are so called assessment, formative and summative evaluations [6]. The e-learning and multimedia evaluations developed by Sage Learning Systems 17 major categories and 105 separate criteria on which e-learning courses can be applied for evaluation [7]. Prasad explains how an evaluation of e-learning should be done. By his idea understanding own value is important. Counting benefits of e-learning, convenient and flexible access, budget-friendly, measurable results and reporting are key points of Prasad view [8]. Petrone offers to use a famous method for evaluation from Kirkpatrick. He thinks that Kirkpatrick model can be applied to measure learning effectiveness of e-learning evaluation in best way [9]. Donald Kirkpatrick developed an evaluation method for educational programs in four level during his dissertation [10]. Level 1 focuses on reaction, level 2 focuses on learning, level 3 is for behavior and level 4 focuses on results. Kirkpatrick's four level evaluation methodology is well known and wide distributed model. Anstey and Watson established a method called "Rubric for E-Learning Tool" Evaluation. Main aim of this method is to identify functionality and success of e-learning. They defined categories: functionality, accessibility, technical, mobile design, privacy, data protection and rights, social presence, teaching presence, cognitive presence. Each category consists of several covering spaces [11]. Bates described nine steps for evaluation of online courses. Decide how you want to teach online is stands as main question for first step. Decide on what kind of online course stands for second step. Work on team defines third step. Build on existing resources explains fourth step. Master the technology describes fifth step. Set appropriate learning goals is linked to sixth step. Design course structure and learning activities is standing for seventh step. Communicate, formulates eighth step and innovate explains ninth step [12].William Horton Consulting offers checklists for course comparison [13]. The quick and systematic way for evaluation is key point of Horton. eLSE Methodology: a Systematic Approach to the e-Learning Systems Evaluation focuses on the most important aspects like Technology, Interaction, Content, Services [14]. The user system interaction is an emphasizing aspect of eLSE method.

\section{METHODS}

The survey included a random sample of 60 students in years first to sixth studying for a bachelor's degree in traditional medicine at the university, with questions related to lectures and seminars, and a 0-100 percent comparison of e-learning and classroom training (Table 1 and 2).

Table 1. Evaluation of lectures during e-learning and classroom training

\begin{tabular}{|c|l|l|c|c|c|c|}
\hline № & \multicolumn{1}{|c|}{ Evaluation indicators } & $\begin{array}{c}\text { Disagree } \\
\text { at all }\end{array}$ & $\begin{array}{c}\text { Up to 30 } \\
\text { percent } \\
\text { agree }\end{array}$ & $\begin{array}{c}\mathbf{3 1 - 5 0} \\
\text { percent } \\
\text { agree }\end{array}$ & $\begin{array}{c}\mathbf{5 1 - 7 5} \\
\text { percen } \\
\text { t agree }\end{array}$ & $\begin{array}{c}\mathbf{7 6 - 1 0 0} \\
\text { percen } \\
\text { t agree }\end{array}$ \\
\hline 1 & The content of the lecture was clear & & & & & \\
\hline 2 & Lecture is comprehensible & & & & \\
\hline 3 & $\begin{array}{l}\text { The teacher was able to use the class } \\
\text { time perfectly for the lecture content }\end{array}$ & & & & & \\
\hline 4 & $\begin{array}{l}\text { It was convenient to teach the lecture } \\
\text { online directly in accordance with } \\
\text { the schedule }\end{array}$ & & & & & \\
\hline 5 & $\begin{array}{l}\text { It was convenient to watch the } \\
\text { lecture on video and study it } \\
\text { independently }\end{array}$ & & & & & \\
\hline
\end{tabular}


Table 2. Assessment of questions related to non-lecture forms during e-learning and classroom training

\begin{tabular}{|c|c|c|c|c|c|c|}
\hline № & Evaluation indicators & $\begin{array}{l}\text { Disagree } \\
\text { at all }\end{array}$ & $\begin{array}{l}\text { Up to } 30 \\
\text { percent } \\
\text { agree }\end{array}$ & $\begin{array}{c}31-50 \\
\text { percent } \\
\text { agree }\end{array}$ & $\begin{array}{l}51-75 \\
\text { percent } \\
\text { agree }\end{array}$ & $\begin{array}{c}76-100 \\
\text { percent } \\
\text { agree }\end{array}$ \\
\hline 1 & $\begin{array}{l}\text { In practice/seminar, I was able to } \\
\text { consolidate the theoretical } \\
\text { knowledge I gained from the } \\
\text { lectures. }\end{array}$ & & & & & \\
\hline 2 & $\begin{array}{l}\text { The practice/seminar has } \\
\text { improved my skills. }\end{array}$ & & & & & \\
\hline 3 & $\begin{array}{l}\text { The practice/seminar was student- } \\
\text { centered. }\end{array}$ & & & & & \\
\hline 4 & $\begin{array}{l}\text { The practice/seminar was aimed at } \\
\text { understanding the profession. }\end{array}$ & & & & & \\
\hline 5 & $\begin{array}{l}\text { It was convenient to go directly to } \\
\text { the practice/seminar online } \\
\text { according to the schedule. }\end{array}$ & & & & & \\
\hline 6 & $\begin{array}{l}\text { It was convenient to watch the } \\
\text { practice/seminar offline and learn } \\
\text { independently. }\end{array}$ & & & & & \\
\hline
\end{tabular}

It consists of five questions to assess the knowledge and skills of the teacher who uses the information technology, five questions to evaluate the suitability of some e-learning activities, and three open-ended questions to name three advantages of the classroom and e-learning. The group surveyed 29 questions in late February 2021 using the Google Form research platform. Statistical analysis was performed using SPSS 26.0 software. Descriptive statistics are calculated as averages and standard deviations for numerical variables, and categorical variables are expressed as frequency and percentage. The survey was conducted using a one-moment model using a questionnaire. The reliability of the survey was 0.97 when the Cronbach's alpha coefficient was used, indicating that the study was very well developed.

\section{Results of Evaluation}

1062 students studied professional "Pharmacy" but only 552 students sent responses and it was $51.98 \%$ of total enrolled students. From them 500 were female and 52 were male students. Out of 97 students studying in a physician of traditional medicine, 60 students or $61.85 \%$ (50 female, 10 male), 25 students or $60.97 \%$ ( 17 female, 8 male) out of 41 students studying in Pharmaceutical Engineering and Technology, 56 students or $72.72 \%$ out of 77 students studying in Nursing \% (54 female, 2 male) students took part in evaluation process. Reason for some students not participating in process was the hard accessibility to the Internet in rural areas.

Of the 80 students studying traditional medicine, $60(75 \%)$ participated in the study voluntarily, with an average age of $25.6 \pm 1.5$. Of the 60 students surveyed, $73.9 \%$ were female, $85 \%$ were in years from second to sixth, or about $70 \%$ of the $2019-2020$ academic year were online. When asked about the environment in which students can use computers, 
$82.7 \%$ said they were at home, $13.2 \%$ said they were in a laboratory, $57 \%$ said they could use the Internet on a public network, and $41 \%$ said they could only use data.

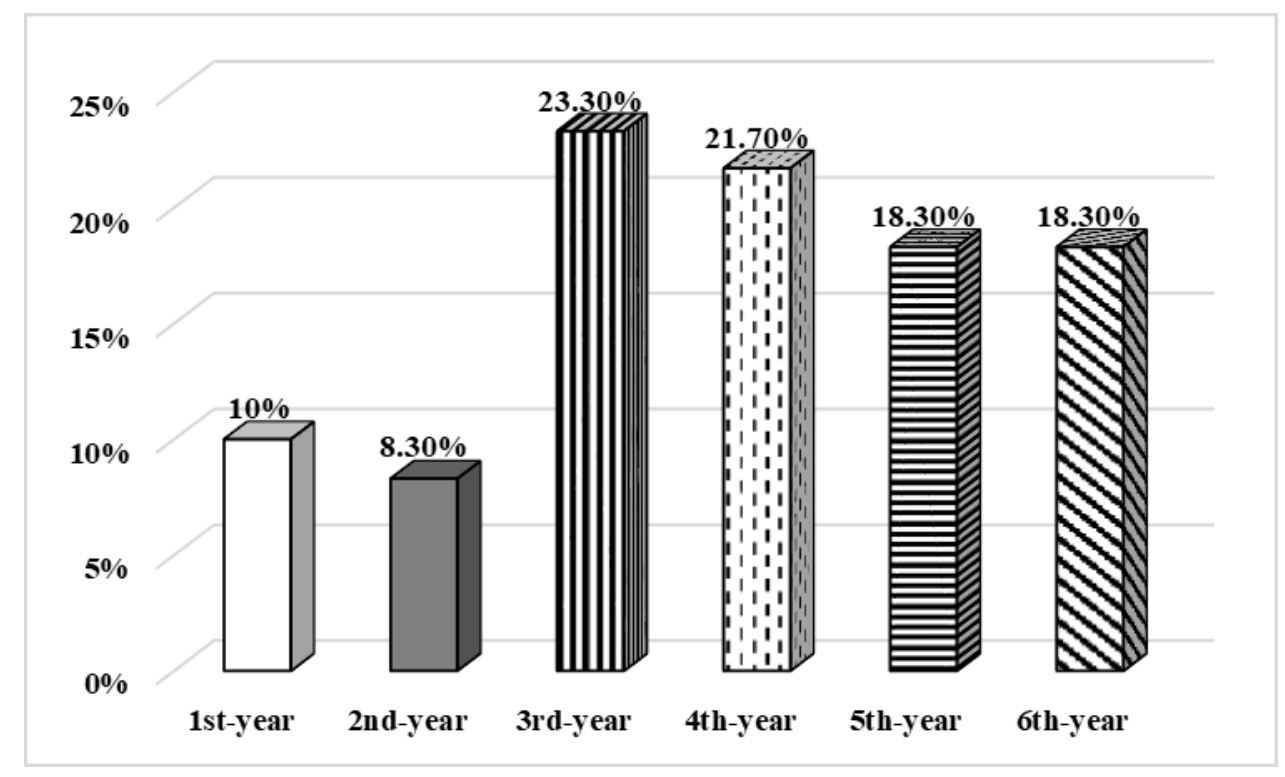

Figure 1. Number of students involved in the survey (Course, percentage)

Of the total students surveyed, $10.0 \%$ were first-year students, $8.3 \%$ were second-year students, $23.3 \%$ were third-year students, $21.7 \%$ were fourth-year students, $18.3 \%$ were fifth-year students, and $18.3 \%$ were sixth-year students. The most enrolled class was the fourth year, and there was no statistical significance between the courses $(\mathrm{P} \leq 0.05)$.

Table 3. The course with the highest score in e-learning

\begin{tabular}{|c|c|c|c|c|c|c|}
\hline № & Evaluation indicators & $\begin{array}{l}\text { Disagree at } \\
\text { all }\end{array}$ & $\begin{array}{l}\text { Up to } 30 \\
\text { percent } \\
\text { agree }\end{array}$ & $\begin{array}{c}31-50 \\
\text { percent } \\
\text { agree }\end{array}$ & $\begin{array}{c}51-75 \\
\text { percent } \\
\text { agree }\end{array}$ & $\begin{array}{c}76-100 \\
\text { percent } \\
\text { agree }\end{array}$ \\
\hline 1. & $\begin{array}{l}\text { The content of the lecture was } \\
\text { clear }\end{array}$ & $\begin{array}{l}2^{\text {nd }} \text { year } \\
20 \%\end{array}$ & $\begin{array}{l}5^{\text {th }} \text { year } \\
27.3 \%\end{array}$ & $\begin{array}{l}4^{\text {th }} \text { year } \\
38.5 \%\end{array}$ & $\begin{array}{l}5^{\text {th }} \text { year } \\
36.4 \%\end{array}$ & $\begin{array}{l}1^{\text {st }} \text { year } \\
66.7 \%\end{array}$ \\
\hline 2. & Lecture is comprehensible & $\begin{array}{l}2^{\text {nd }} \text { year } \\
20 \%\end{array}$ & $\begin{array}{l}4^{\text {th }} \text { year } \\
23.1 \%\end{array}$ & $\begin{array}{l}6^{\text {th }} \text { year } \\
45.5 \%\end{array}$ & $\begin{array}{l}4^{\text {th }} \text { year46 } \\
.2 \%\end{array}$ & $\begin{array}{l}1^{\text {st }} \text { year } \\
66.7 \%\end{array}$ \\
\hline 3. & $\begin{array}{l}\text { The teacher was able to use } \\
\text { the class time perfectly for the } \\
\text { lecture content }\end{array}$ & $\begin{array}{l}2^{\text {nd }} \text { year } \\
40.0 \%\end{array}$ & $\begin{array}{l}5^{\text {th }} \text { year } \\
18.2 \%\end{array}$ & $\begin{array}{l}6^{\text {th }} \text { year } \\
27.3 \%\end{array}$ & $\begin{array}{l}3^{\text {rd }} \text { year } \\
42.9 \%\end{array}$ & $\begin{array}{l}1^{\text {st }} \text { year } \\
50.0 \%\end{array}$ \\
\hline 4. & $\begin{array}{l}\text { It was convenient to teach the } \\
\text { lecture online directly in } \\
\text { accordance with the schedule }\end{array}$ & $\begin{array}{l}2^{\text {nd }} \text { year } \\
40.0 \%\end{array}$ & $\begin{array}{l}3^{\text {rd }} \text { year } \\
28.6 \%\end{array}$ & $\begin{array}{l}2^{\text {nd }} \text { year } \\
40.0 \%\end{array}$ & $\begin{array}{l}1^{\text {st }} \text { year33 } \\
.3 \%\end{array}$ & $\begin{array}{l}6^{\text {th }} \text { year } \\
36.4 \%\end{array}$ \\
\hline 5. & $\begin{array}{l}\text { It was convenient to watch } \\
\text { the lecture on video and study } \\
\text { it independently }\end{array}$ & $\begin{array}{l}2^{\text {nd }} \text { year } \\
40.0 \%\end{array}$ & $\begin{array}{l}5^{\text {th }} \text { year } \\
27.3 \%\end{array}$ & $\begin{array}{l}3^{\text {rd }} \text { year } \\
40.0 \%\end{array}$ & $\begin{array}{l}3^{\text {rd }} \text { year } \\
35.7 \%\end{array}$ & $\begin{array}{l}6^{\text {th }} \text { year } \\
36.4 \%\end{array}$ \\
\hline
\end{tabular}


International Journal on Integrating Technology in Education (IJITE) Vol.10, No.2, June 2021

In Table 3,33.3\% of the students surveyed said that the content of the lectures was apparent during the e-learning. The highest score was $66.7 \%$ of first-year students who said that the lecture's content was straightforward, while the worst score was that $20 \%$ of second-year students did not agree $(\mathrm{P} \leq 0.56)$.

$33.3 \%$ of the surveyed students agreed that 76-100 percent agreed with whether the teacher was able to use the class time for the lecture content, and $6.7 \%$ disagreed. Fifty percent of first-year students said that the teacher could make full use of class time for lecture content, while $40 \%$ of second-year students said they did not agree $(\mathrm{P} \leq 0.40)$.

$26.7 \%$ of the students who participated in the survey said it would be appropriate (76-100\% agree) to go online according to the lecture schedule, while $8.3 \%$ disagreed. $36.4 \%$ of 6 th-year students agreed that online classes were appropriate, while $40 \%$ of 2 nd-year students disagreed (P $\leq 0.15)$.

$26.7 \%$ of the students in the survey agreed that it would be appropriate (31-50\% agree) to study the lecture offline independently, while 5\% disagreed. $36.4 \%$ of 5th-year and 6th-year students considered it appropriate to study independently, while $40 \%$ of 2 nd-year students disagreed ( $\mathrm{P} \leq$ $0.06)$.

Table 4. The course with the highest score during the classroom training

\begin{tabular}{|c|c|c|c|c|c|c|}
\hline № & Evaluation indicators & $\begin{array}{l}\text { Disagree } \\
\text { at all }\end{array}$ & $\begin{array}{c}\text { Up to } 30 \\
\text { percent } \\
\text { agree }\end{array}$ & $\begin{array}{c}\text { 31-50 } \\
\text { percent } \\
\text { agree }\end{array}$ & $\begin{array}{c}51-75 \\
\text { percent } \\
\text { agree }\end{array}$ & $\begin{array}{c}76-100 \\
\text { percent } \\
\text { agree }\end{array}$ \\
\hline 1 & The content of the lecture was clear & - & - & $\begin{array}{l}3^{\text {rd }} \text { year } \\
30.8 \%\end{array}$ & $\begin{array}{l}3^{\text {rd }} \text { year } \\
53.8 \%\end{array}$ & $\begin{array}{l}1^{\text {st }} \text { year } \\
80.0 \%\end{array}$ \\
\hline 2 & Lecture is comprehensible & - & - & $\begin{array}{l}1^{\text {st }} \text { year } \\
33.3 \%\end{array}$ & $\begin{array}{l}2^{\text {nd }} \text { year } \\
50.0 \%\end{array}$ & $\begin{array}{l}2^{\text {nd }} \text { year } \\
80 \%\end{array}$ \\
\hline 3 & $\begin{array}{l}\text { The teacher was able to use the class } \\
\text { time perfectly for the lecture content }\end{array}$ & - & - & $\begin{array}{l}1^{\text {st }} \text { year } \\
50 \%\end{array}$ & $\begin{array}{l}3^{\text {rd }} \text { year } \\
50 \%\end{array}$ & $\begin{array}{l}2^{\text {nd }} \text { year } \\
80 \%\end{array}$ \\
\hline
\end{tabular}

In Table 4, 38.3\% of the students surveyed said that the lecture's content was straightforward during the classroom training, while no student disagreed. The highest score was given by $80 \%$ of first-year students who said that the content of the lecture was clear $(\mathrm{P}=0.005, \mathrm{P} \leq 0.05)$.

While $40 \%$ of the students surveyed said that the lecture was apparent during the classroom, no students disagreed. $80 \%$ of 2 nd year students rated the lecture as clear $(\mathrm{P}=0.00, \mathrm{P} \leq 0.05)$.

During the classroom training, $46.7 \%$ of the students surveyed said that the teacher could make full use of the class time for the lecture content, but no student disagreed. Eighty percent of the second-year students rated the teacher to use the class time ideally for the lecture content $(\mathrm{P} \leq$ $0.08)$. 
International Journal on Integrating Technology in Education (IJITE) Vol.10, No.2, June 2021

Table 5. Online practice/seminar

\begin{tabular}{|c|c|c|c|c|c|c|}
\hline № & Evaluation indicators & $\begin{array}{l}\text { Disagree } \\
\text { at all }\end{array}$ & $\begin{array}{l}\text { Up to } 30 \\
\text { percent } \\
\text { agree }\end{array}$ & $\begin{array}{l}\text { 31-50 } \\
\text { percen } \\
\text { t agree }\end{array}$ & $\begin{array}{c}51-75 \\
\text { percent } \\
\text { agree }\end{array}$ & $\begin{array}{l}76-100 \\
\text { percen } \\
\text { t agree }\end{array}$ \\
\hline 1 & $\begin{array}{l}\text { In practice/seminar, I was able to } \\
\text { consolidate the theoretical knowledge I } \\
\text { gained from the lectures. }\end{array}$ & $\begin{array}{l}2^{\text {nd }} \text { year } \\
20 \%\end{array}$ & $\begin{array}{l}5^{\text {th }} \text { year } \\
27.3 \%\end{array}$ & $\begin{array}{l}4^{\text {th }} \text { year } \\
38.5 \%\end{array}$ & $\begin{array}{l}5^{\text {th }} \text { year } \\
36.4 \%\end{array}$ & $\begin{array}{l}6^{\text {th }} \text { year } \\
36.4\end{array}$ \\
\hline 2 & $\begin{array}{l}\text { The practice/seminar has improved my } \\
\text { skills. }\end{array}$ & $\begin{array}{l}1^{\text {st }} \text { year } \\
16,7 \%\end{array}$ & $\begin{array}{l}2^{\text {nd }} \text { year } \\
60 \%\end{array}$ & $\begin{array}{l}4^{\text {th }} \text { year } \\
42.9 \%\end{array}$ & $\begin{array}{l}5^{\text {th }} \text { year } \\
36.4 \%\end{array}$ & $\begin{array}{l}6^{\text {th }} \text { year } \\
27.3 \%\end{array}$ \\
\hline 3 & $\begin{array}{l}\text { The practice/seminar was student- } \\
\text { centered. }\end{array}$ & $\begin{array}{l}1^{\text {st }} \text { year } \\
16,7 \%\end{array}$ & $\begin{array}{l}5^{\text {th }} \text { year } \\
27.3 \%\end{array}$ & $\begin{array}{l}4^{\text {th }} \text { year } \\
38.5 \%\end{array}$ & $\begin{array}{l}5^{\text {th }} \text { year } \\
36.4 \%\end{array}$ & $\begin{array}{l}1^{\text {st }} \text { year } \\
50 \%\end{array}$ \\
\hline 4 & $\begin{array}{l}\text { The practice/seminar was aimed at } \\
\text { understanding the profession. }\end{array}$ & $\begin{array}{l}1^{\text {st }} \text { year } \\
16,7 \%\end{array}$ & $\begin{array}{l}2^{\text {nd }} \\
\text { year } 40 \%\end{array}$ & $\begin{array}{l}1^{\text {st }} \text { year } \\
45.5 \%\end{array}$ & $\begin{array}{l}3^{\text {rd }} \text { year } \\
35.4 \%\end{array}$ & $\begin{array}{l}6^{\text {th }} \text { year } \\
45 \%\end{array}$ \\
\hline 5 & $\begin{array}{l}\text { It was convenient to go directly to the } \\
\text { practice/seminar online according to the } \\
\text { schedule. }\end{array}$ & $\begin{array}{l}1^{\text {st }} \text { year } \\
16,7 \%\end{array}$ & $\begin{array}{l}2^{\text {nd }} \text { year } \\
40 \%\end{array}$ & $\begin{array}{l}1^{\text {st }} \text { year } \\
50 \%\end{array}$ & $\begin{array}{l}3^{\text {rd }} \text { year } \\
37.4 \%\end{array}$ & $\begin{array}{l}6^{\text {th }} \text { year } \\
36.4 \%\end{array}$ \\
\hline 6 & $\begin{array}{l}\text { It was convenient to watch the } \\
\text { practice/seminar offline and learn } \\
\text { independently. }\end{array}$ & $\begin{array}{l}1^{\text {st }} \text { year } \\
33.3 \%\end{array}$ & $\begin{array}{l}2^{\text {nd }} \text { year } \\
40 \%\end{array}$ & $\begin{array}{l}3^{\text {rd }} \text { year } \\
57.3 \%\end{array}$ & $\begin{array}{l}1^{\text {st }} \text { year } \\
50 \%\end{array}$ & $\begin{array}{l}6^{\text {th }} \text { year } \\
36.4\end{array}$ \\
\hline
\end{tabular}

In Table 5, 26.7\% of the students surveyed said they had consolidated $50 \%$ of the theoretical knowledge gained from the lectures during the e-learning practice. In comparison, $6.7 \%$ said it was not enough. $36.4 \%$ of 6th-year students answered that they had confirmed their theoretical knowledge, while $20 \%$ of 2 nd-year students said they failed $(\mathrm{P}=0.188 \mathrm{P} \leq 0.05) .31 .7 \%$ of the students who participated in the survey said that 50 percent of the practice/seminar improved their skills during e-learning, while $6.7 \%$ said that it was not enough. $27.3 \%$ of 6th-year students answered that they had improved their skills (76-100), and 16.7\% of 1st-year students said they failed $(\mathrm{P}=0.15)$.

$28.7 \%$ of the students surveyed said that the e-learning course was student-centered, while $5 \%$ said it was insufficient. 50\% of first-year students could have student-centered training, and $16.7 \%$ of first-year students were unsuccessful $(\mathrm{P} \leq 0.56)$.

$26.7 \%$ of the students surveyed assessed the practice/seminar as moderate (31-50), and 3.3\% considered it insufficient. Forty-five percent of sixth-year students evaluated it as a way to understand their profession, while $16.7 \%$ of first-year students said they did not $(\mathrm{P}=0.13)$.

In e-learning, $30 \%$ of the students surveyed evaluated it as moderate (31-50), while $10 \%$ rated it insufficient. $36.4 \%$ of 6th-year students considered it appropriate (76-100\%) to go online according to the schedule, while $16.7 \%$ of 1 st-year students did not $(\mathrm{P}=0.09)$.

In e-learning, $28.3 \%$ of the students surveyed said that it was appropriate (51-75\%) to study the internship independently, and $10 \%$ said that it was not enough. $36.4 \%$ of 6th-year students considered it appropriate (76-100\%) to study independently, while $33.3 \%$ of 1st-year students did $\operatorname{not}(\mathrm{P}=0.02, \mathrm{P} \leq 0.05)$. 
International Journal on Integrating Technology in Education (IJITE) Vol.10, No.2, June 2021

Table 6. High marks given in the classroom training

\begin{tabular}{|l|l|c|c|c|c|c|}
\hline № & \multicolumn{1}{|c|}{ Evaluation indicators } & $\begin{array}{c}\text { Disagree } \\
\text { at all } \\
\text { percent } \\
\text { agree }\end{array}$ & $\begin{array}{c}\text { Up to 30 } \\
\text { percent } \\
\text { agree }\end{array}$ & $\begin{array}{c}\mathbf{3 1 - 5 0} \\
\text { percent } \\
\text { agree }\end{array}$ & $\begin{array}{c}\mathbf{5 1 - 7 5} \\
\text { percent } \\
\text { agree }\end{array}$ \\
\hline 1 & $\begin{array}{l}\text { In practice/seminar, I was able to } \\
\text { consolidate the theoretical } \\
\text { knowledge I gained from the } \\
\text { lectures. }\end{array}$ & - & - & $\begin{array}{l}4^{\text {th }} \text { year } \\
53.8 \%\end{array}$ & $\begin{array}{l}3^{\text {rd }} \text { year } \\
50 \%\end{array}$ & $\begin{array}{l}2^{\text {nd }} \text { year } \\
80 \%\end{array}$ \\
\hline 2 & $\begin{array}{l}\text { The practice/seminar has improved } \\
\text { my skills. }\end{array}$ & - & - & $\begin{array}{l}4^{\text {th }} \text { year } \\
61.5 \%\end{array}$ & $\begin{array}{l}3^{\text {rd }} \text { year } \\
42.7 \%\end{array}$ & $\begin{array}{l}2^{\text {nd }} \text { year } \\
80 \%\end{array}$ \\
\hline 3 & $\begin{array}{l}\text { The practice/seminar was student- } \\
\text { centered. }\end{array}$ & - & - & $\begin{array}{l}4^{\text {th }} \text { year } \\
46.5 \%\end{array}$ & $\begin{array}{l}3^{\text {rd }} \text { year } \\
57.3 \%\end{array}$ & $\begin{array}{l}2^{\text {nd }} \text { year } \\
80 \%\end{array}$ \\
\hline 4 & $\begin{array}{l}\text { The practice/seminar was aimed at } \\
\text { understanding the profession. }\end{array}$ & - & - & $\begin{array}{l}1^{\text {st }} \text { year } \\
45.5 \%\end{array}$ & $\begin{array}{l}3^{\text {rd }} \text { year } \\
35.4 \%\end{array}$ & $\begin{array}{l}5^{\text {th }} \text { year } \\
54 \%\end{array}$ \\
\hline
\end{tabular}

In Table $6,31.3 \%$ of the students surveyed said they could consolidate the theoretical knowledge gained from the lectures in the classroom, while none of the students disagreed. Eighty percent of second-year students said they had consolidated their theoretical knowledge $(\mathrm{P} \leq 0.05)$.

$33.3 \%$ of the students who participated in the survey said that the internship improved their skills during the classroom training, but no student disagreed. Of these, $80 \%$ of 2 nd-year students said they improved (76-100\%) my skills $\mathrm{P} \leq 0.05)$.

While $35 \%$ of the students surveyed said that practice/seminar could be student-centered during classroom training, no students disagreed. Of these, $80 \%$ of 2 nd-year students were rated as student-centered $(76-100 \%)(\mathrm{P}=0.03)(\mathrm{P} \leq 0.05)$.

$33.3 \%$ of the students surveyed said that the practice/seminar aimed to understand their profession during the classroom training, while no students disagreed. Of these, 54\% of 5th year students evaluated their understanding of their profession $(76-100 \%)(\mathrm{P}=0.14)(\mathrm{P}>0.05)$.

\section{Conclusions}

Main aim of this paper is to share evaluation case of online courses during pandemic period in Mongolian University of Pharmaceutical Sciences. This evaluation was the first case of selfevaluation of online courses for the professors. Self-evaluations such as this helps the professors get deeper understanding about e-learning process, different roles and functions of involved groups, expectations of students during online teaching [15]. The assessment of the students involved in the study varies depending on the year of study. In particular, second-year students took most of the courses online, and self-study of e-lectures (40\%) and online practice/seminar $(80 \%)$ were considered inappropriate. In e-learning, lectures are clear $(\mathrm{P}=0.01)(\mathrm{P}>0.05)$.Eighty percent of the first-year students surveyed said that the content of the lectures was straightforward during the classroom training $(P=0.005, \mathrm{P} \leq 0.05)$. In e-learning, 36.4\% of 6thyear students considered it appropriate to study the internship on video and study independently, while $33.3 \%$ of 1 st-year students did not. The responses are statistically significant. Although the undergraduate medical practice is more effective in a hospital environment, the study found that e-learning and classroom training can be combined, depending on the circumstances. 
International Journal on Integrating Technology in Education (IJTTE) Vol.10, No.2, June 2021

\section{REFERENCES}

[1] Pharmaceutical Indicators - 2018, Annual report from Ministry of Health, Mongolia, pp.16-19. Online available: http://hdc.gov.mn/media/files/2018_Kedu7Vn.pdf

[2] Zultsetseg, N., (2021) Online learning in the MUPS, Journal of Mongolian Pharmacy and Pharmacology. V.1 (18), p.131

[3] Government of Mongolia. 2019 Vision 2050, a project to be implemented within the framework of Mongolia's long-term development policy, Package Discussion of the Education. Ulaanbaatar

[4] Resolution No. 52 of the Parliament of Mongolia. May 13, 2020. "Vision-2050" On approving Mongolia's long-term development policy. Government House, Ulaanbaatar

[5] B. Munkhchimeg. A study of the use of data mining in training management systems for electric learning assessment. Data and Knowledge Management. MMT 2015

[6] Christopher Pappas, (2011) Introduction to Evaluation in eLearning, Online available:https://www.efrontlearning.com/blog/2011/01/introduction-to-evaluation-in-elearning.html

[7] Sage Learning Systems, (2011) e-Learning Evaluation, Online available:http://www.sagelearning.com/papers/Evaluation\%20Forms.pdf

[8] RK Prasad, (2020) The Five Evaluation Levels Of your eLearning Program, online article in eLearning Industry, Online available: https://elearningindustry.com/five-evaluation-levels-ofelearning-program

[9] Paul Petrone, (2017) The Best Way to Use the Kirkpatrick Model, Online available: https://www.linkedin.com/business/learning/blog/learning-and-development/the-best-way-to-use-thekirkpatrick-model-the-most-common-way

[10] Kirkpatrick, D. L. (1959). "Techniques for evaluating training programs", Journal of American Society of Training Directors, Vol.13. No.3. pp.21-26.

[11] Lauren Anstey and Gavan Watson, (2018) A Rubric for Evaluating E-Learning Tools in Higher Education, Educause, Online available: https://er.educause.edu/articles/2018/9/a-rubric-forevaluating-e-learning-tools-in-higher-education

[12] Tony Bate, (2012) Nine steps to quality online learning: Step 9: Evaluate and innovate, Online learning and distance education recourses, Online available:https://www.tonybates.ca/2012/07/09/nine-steps-to-quality-online-learning-step-9-evaluateand-innovate/

[13] Horton, W. (2001) Evaluating E-Learning. American Society for Training and Development, Alexandria.

[14] Lanzilotti, R., Ardito, C., Costabile, M. and Angeli, A. (2006) A Systematic Approach to the eLearning Systems Evaluation. School of Informatics. 9, 4: pp.42-53.

[15] Uranchimeg Tudevdagva, Bazarragchaa Sodnom, Selenge Erdenechimeg, (2021) The Evaluation Case Study Of Online Course During Pandemic Period In Mongolia, Computer Science \& Information Technology Vol 11 (06): pp.29-40 